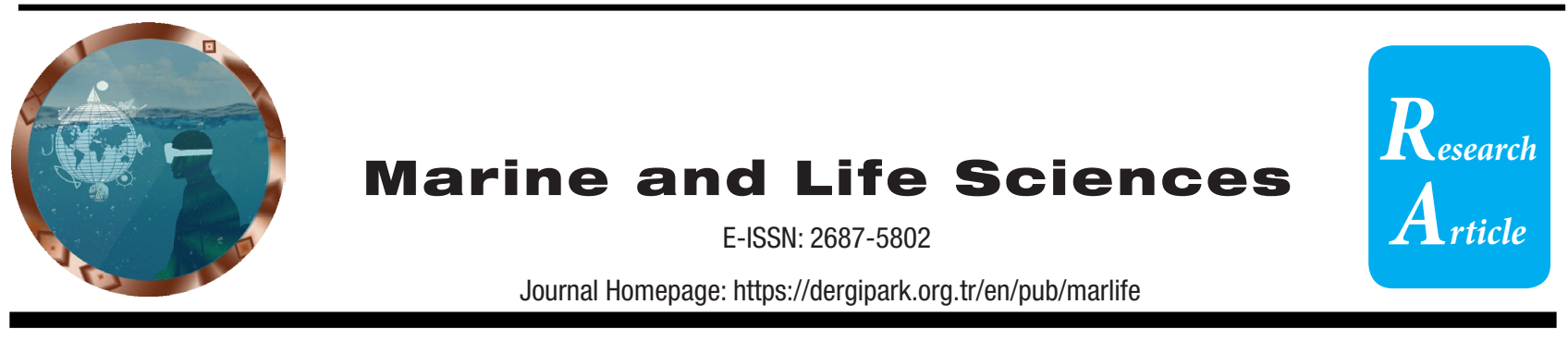

\title{
Biological traits of a data deficient species in the Asi River: Barbus lorteti (Sauvage, 1882)
}

\author{
Sevil Demirci*1, Șükran Yalçın Özdilek²
}

*Corresponding author: sevil.demirci@iste.edu.tr

Received:29.05.2021

Accepted: 30.06 .2021

\begin{tabular}{l} 
Affiliations \\
\hline 'Department of Marine Techonolgies, Faculty \\
of Marine Sciences and Technology, \\
Iskenderun Technical University, \\
Iskenderun-Hatay, TURKEY \\
'Department of Biology, Faculty of Science \\
and Art, Çanakkale Onsekiz Mart University, \\
Çanakkale, TURKEY
\end{tabular}

\section{Keywords}

Population dynamics

Freshwater fish

Growth parameters

\section{ABSTRACT}

This study was conducted using 201 Barbus lorteti(Sauvage, 1882) individuals, obtained in 1997 from Asi River. In this study, the length-weight and age-weight parameters were estimated using the von Bertalanffy growth equation. The total length for the individuals was varied between 7.4 and $31.0 \mathrm{~cm}$ with an average of $18.37 \mathrm{~cm}$. The distribution of weight was fixed as 3.8 and $274.9 \mathrm{~g}$ and $82.57 \pm 4.3 \mathrm{~g}$ in average. The length-weight relationship was estimated as $\mathrm{W}=$ $0.013^{*} L^{2.97}$. In the age based scale readings-of the individuals in the sampling the age classes were ranging between I-IV. For this species, von Bertalanffy equation in length growth were estimated as $L_{t}=28.45\left[1-\mathrm{e}^{-0.43(t+(-0.23))}\right]$, and the equation in weight growth was estimated as $W_{t}=382.76^{*}\left[1-e^{-0.34(t+(-0.19)}\right]^{2.97}$. The growth performance index $(\Phi)$ and Condition factor was estimated as 2.56 and 1.11 , respectively.

\section{Introduction}

Turkey, with its special geographical location and freshwater potential, contains many endemic and cosmopolitan fish species. (Innal and Erk'akan, 2006). Approximately 387 freshwater fish species were determined as endemic (Froese and Pauly, 2010).

Barbus lorteti is an endemic species, belonging to the family of Cyprinidae, mainly distrubuted in the lower parts of Asi River from Syria to Turkey. IUCN assessed this species as data defficient (DD) because of the absence of reliable data on distribution, abundance, trend and threat of this species (Crivelli, 2018). The population of this species has decreased after collection of the specimens, and various attempts to collect them species is wasted in last decade. The population of this species has decreased dramatically in the last 25 years (Karataș et al., 2021). The changes and deteriorations occurred in the freshwater ecosystems, emerged more devastatingly such as the extinction of the biological diversity (Sala et al., 2000). The excessive use of the water, agricultural irrigation and extreme low tide as aresult of dam and set applications change the habitat characteristics of the river (Crivelli,1995). It is asserted that destruction in Asi River caused the deterioration of the species as bringing over exploitation with it. According to the commercial fishing activities, the existence of this species could be mentioned especially as being in the lower parts of Asi River till the years of 1990s (Demirci and Demirci, 2009). After this term, following the negativities (partial water reduction, drying, domestic waste, industrial pollution, agricultural activities and irrigation) occurred in Asi River, no $B$. lorteti individuals were encountered in the main river bed (Yalçın, 1999).

Although little is known about concerning the checklist and systematic features of this species (Çiçek et al., 2018), the little was known about the population structure, habitat and ecological features of this species. Age-length and age- 
weight features belonging to this species were given for the first time. In addition, in this study, the reasons for the deterioration of the $B$. lorteti population are tried to be explained by comparing the biological characteristics of Barbus luteus which is another endemic specie still existing in the region (Yalcin et al., 2004; Gokçek and Akyurt, 2008).

\section{Material and Methods}

The Asi River, also named as Orontes, was located in both the borders of Syria and Turkey. The river rose from the Bekaa Valley in Lebanon and reached after in Syria. $94 \mathrm{~km}$ of its water were located in the borders of Turkey (Yalçın Özdilek et al., 2006; Demirci et al., 2020). In the last set, it flowed into Mediterrenean from Samandag (Yalcin, 1999; Demirci et al., 2012; Demirci et al., 2016). There are many fish passages in the Asi River (Demirci et al., 2018). The research area, representing four different capture areas, is shown in Figure 1.

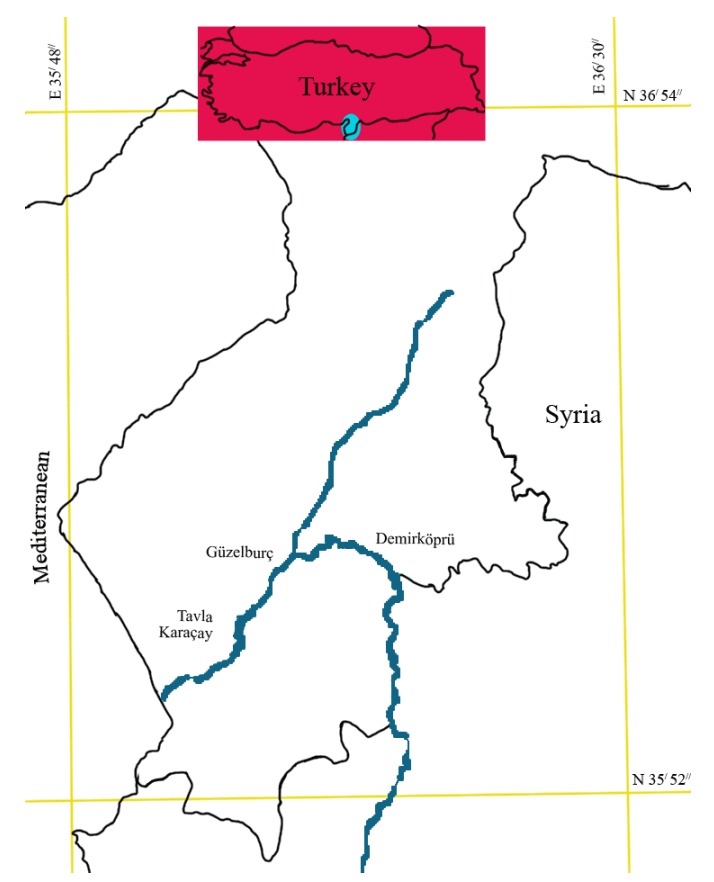

Figure 1. Map of the research area with four different catching (Demirköprü, Güzelburç, Tavla and Karaçay) region.

$B$. lorteti samples were obtained from the local fishers who threw fyke net, electro-shocker and trammel net. These catching gears were thrown in the evening and then collected in the next morning. 201 individuals were sampled and brought to the laboratory by being fixed in the $4 \%$ of formalin solution following the preliminary studies. The length measurements of the fish samples were realized by fish measuring scale with $1 \mathrm{~mm}$ interval and the weight measurements were done with digital scale with $0.1 \mathrm{~g}$. In age determination, scales were used. For this purpose, the scales taken from the left anterior-dorsal region of the fish were washed with distilled water and kept in $3 \% \mathrm{NaOH}$ solution for 3-6 hours, dipped in $96 \%$ ethyl alcohol and kept for 3-6 hours. After washing with distilled water for 30 minutes, it was dried and fixed between two slides and became ready for examination (Lagler, 1966). These preparations were aged in a small magnifying binocular microwave. In the estimation of the length-weight relationship, the regression analysis method was used (Ricker, 1975).

$W=a L^{b}$

Here the ' $W$ ' indicated the total weight of the fish in gram; ' $L$ ' indicated the total length of the fish in $\mathrm{cm}$, ' $a$ ' and ' $b$ ' coefficients indicated the regression parameters, which vary according to the species. von Bertalanffy growth equation was estimated by the least squares method based on the lengths and weights observed in every age groups (Beverton and Holt, 1957).

$\mathrm{L}_{\mathrm{t}}=\mathrm{L}_{\infty}{ }^{*}\left[1-\mathrm{e}-\mathrm{K}^{*}(\mathrm{t}-\mathrm{tol})\right]$

$W_{t}=W_{\infty}^{*}\left[1-e^{K^{*}(t-t o)}\right]^{b}$

The " $L_{t}$ ", the fish length in $t$ age, " $L_{\infty}$ ", the asymptotic length based on the growth gradient in fish, " $\mathrm{K}^{-1}$ " the growth coefficient in length and the " $\mathrm{t}_{0}$ " the hypothetical age, as based upon the weight is zero. Similarly " $W_{t}$ ", the fish weight in $t$ age, " $W_{\infty}$ ", the asymptotic weight based on the growth gradient in fish, " $\mathrm{K}^{-1}$ " indicates the growth coefficient in weight and the " $\mathrm{t}_{0}$ " indicates the hypothetical age, as based upon the weight is zero.

The growth performance index used to compare the growth rate in fish was fixed as taking advantage of the formula of $\Phi^{\prime}=\operatorname{logK}^{-1}+2 \log \mathrm{L}_{\infty}$ (Sparre and Venema, 1998). In this equation; $\Phi=$ shows the growth performance index, $L_{\infty}=$ asymptotic length $(\mathrm{cm}), \mathrm{K}^{-1}=$ Brody's growth coefficient (year $\left.{ }^{-1}\right)$.

Fulton's Condition Factor was estimated and the arithmetical average of these were taken. The Fulton Condition Factor was stated in the below formula (Holden and Raitt, 1974).

$\mathrm{K}=\left(\mathrm{W}^{*} 100\right) / \mathrm{L}^{\mathrm{b}}$

As the species has currently not observed in nature, the genetic analyses provied that the samples obtained in the research belonged to the species of $B$. lorteti. In the genetic structure analysis, from the preferred molecular methods, 
the mtDNA-RFLP analysis method was used (Watanabe, 2018).

\section{Results}

The age distribution of $201 B$. lorteti specie which were obtained from four different regions of Asi River was ranged between I-VI. The majority of the population in the region was constituted by the individuals in the age intervals of II and III (73 and 65). Respectively, the number of species and age; there were 43 items of $B$. lortetisamples in I. age, 14 of them in IV. age, 6 of them in V. age, 4 of them in VI. age. The number of individuals based on the ages were shown in Table 1.

Table1. Age- Length size distributions of Barbus Iortetifrom Asi River.

\begin{tabular}{cccccccc}
\hline $\begin{array}{c}\text { Length } \\
\text { Class } \\
\text { (cm) }\end{array}$ & I & II & III & IV & V & VI & Total \\
\cline { 2 - 6 } & 2 & & & & & & 2 \\
10 & 16 & & & & & & 16 \\
12 & 19 & 13 & & & & & 32 \\
14 & 6 & 6 & 5 & & & & 17 \\
16 & & 23 & 12 & & & & 35 \\
18 & & 11 & 11 & & & & 22 \\
20 & & 15 & 8 & 1 & & & 24 \\
22 & & 5 & 11 & 2 & & & 18 \\
24 & & & 14 & 10 & 2 & & 26 \\
26 & & & & 1 & 3 & 2 & 6 \\
28 & & & & & & 2 & 2 \\
30 & & & & & 1 & & 1 \\
\hline Total & 43 & 73 & 61 & 14 & 6 & 4 & 201 \\
\hline Mean & 12.37 & 17.62 & 20.67 & 24.14 & 27.00 & 28.35 & 18.37 \\
\hline Standard & 1.52 & 2.97 & 3.20 & 1.36 & 1.82 & 0.74 & 4.80 \\
Deviation & & & & & & & \\
\hline
\end{tabular}

It was determined that the length distribution of the samples was between 7.4 and $31.0 \mathrm{~cm}$. When all data are taken into account, the average total length of this population starting from the age of I to VI, were found to be $12.37 \mathrm{~cm}, 17.62 \mathrm{~cm}$, $20.67 \mathrm{~cm}, 24.14 \mathrm{~cm}, 24.55 \mathrm{~cm}$, and $28.35 \mathrm{~cm}$, respectively. When the length distribution of the sampled population was examined, the majority of the stock was constituted by the individuals being $17-20 \mathrm{~cm}$ total length interval.

The weight distributions of the sampled population by age were found as $109,19.90 \mathrm{~g}, 52.13 \mathrm{~g}, 117.69$ $\mathrm{g}, 175.69 \mathrm{~g}, 203.55 \mathrm{~g}$ starting from the first age to last age, respectively. The weight of $\mathrm{VI}$ age group was found to be $268.95 \mathrm{~g}$ in average (Table 2).

According to the measured weights, the minimum and the maximum values were measured as respectively 3.8 and $299.0 \mathrm{~g}$, respectively.
Table 2. Weight distributions of Barbus lortetifrom Asi River.

\begin{tabular}{|c|c|c|c|c|c|c|c|}
\hline \multirow{2}{*}{$\begin{array}{l}\text { Weight } \\
\text { Class } \\
\text { (g) }\end{array}$} & \multicolumn{6}{|c|}{ Age Groups (year) } & \multirow{2}{*}{ Total } \\
\hline & I & II & III & IV & $\mathbf{v}$ & Vı & \\
\hline 25 & 36 & 1 & & & & & 37 \\
\hline 50 & 7 & 33 & & & & & 40 \\
\hline 75 & & 34 & 2 & & & & 36 \\
\hline 100 & & 5 & 17 & & & & 22 \\
\hline 125 & & & 21 & & & & 21 \\
\hline 150 & & & 11 & & & & 11 \\
\hline 175 & & & 6 & 11 & 1 & & 18 \\
\hline 200 & & & 3 & 1 & & & 4 \\
\hline 225 & & & 1 & 1 & 4 & & 6 \\
\hline 250 & & & & 1 & 1 & 1 & 3 \\
\hline 275 & & & & & & 2 & 2 \\
\hline 300 & & & & & & 1 & 1 \\
\hline Total & 43 & 73 & 61 & 14 & 6 & 4 & 201 \\
\hline Means & 19.90 & 52.13 & 117.69 & 175.69 & 203.55 & 268.95 & 82.57 \\
\hline $\begin{array}{l}\text { Standard } \\
\text { Deviation }\end{array}$ & 5.21 & 14.15 & 31.65 & 22.69 & 17.69 & 21.58 & 60.99 \\
\hline
\end{tabular}

The mean weight value of the population was estimated as $82.57 \mathrm{~g}$. According to the 201 items obtained from the Asi River B. lorteti population, the total length $(\mathrm{cm})$ and weight $(\mathrm{g})$ regression parameters were determined. At the end of this regression analysis, the relationship was found as $\mathrm{W}=0.013 \mathrm{~L}^{2.94}$. According to the $\mathrm{b}$ coefficient estimated in this formula, the weight and the length regarding this species revealed an isometric increase (Figure 2).

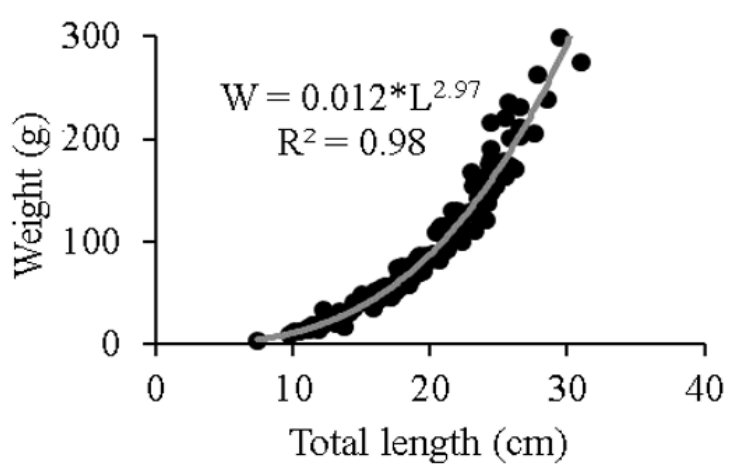

Figure 2. The relationship between length and weight of Barbus lortetifrom the Asi River.

According to the von Bertalanffy equation, the growth model of the mentioned population in age and length was found as: $L_{t}=28.45^{\star}\left[1-\mathrm{e}^{-0.43(t+(-0.23))}\right]$ (Figure 3). The growth performance index for the fish species was estimated as $\Phi=2.56$. Likewise, the growth model in weight estimated in accordance to von Bertalanffy equation was fixed as $\mathrm{W}_{\mathrm{t}}=501.04\left[1-\mathrm{e}^{-0.22(t+(-1.05)}\right]^{2.97}$ (Figure 4). 


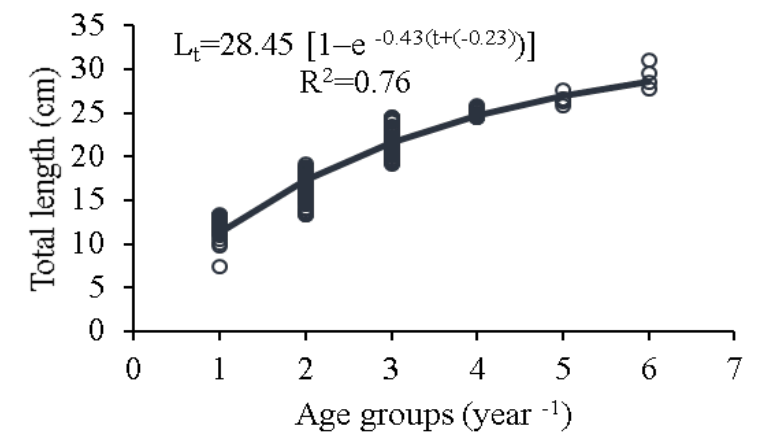

Figure 3. Length size and age von-Bertalanfy growth arameter of Barbus lortetifrom Asi River.

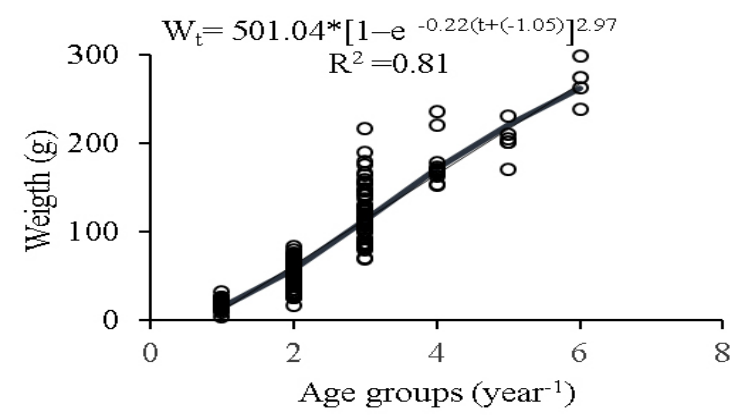

Figure 4. Age and weight von-Bertalanfy growth parameter of Barbus lortetifrom Asi River.

The condition factor estimated from the $B$. lorteti population is shown in Figure 5 . While the mean condition factor was estimated as 1.11 the maximum and the minimum condition factor was found as 1.82 and 0.68 , respectively.

Statistical difference between the measured length and weight values were investigated by Khi Square $\left(X^{2}\right)$ Test.

\section{Discussion}

In this study, biology of the $B$. lorteti, the reasons of the stock's precipitation in Asi River where their population were about to dissappear were tried to be determined. On the other hand the $B$. luteus population, which was sampled in Asi River in a similar way in the same and near period, was continuing its stock (Yalçın Ozdilek et al., 2004). In this context, it would be beneficial to discuss some of the biological and population features of these two species in this part of the article to make comparison. Also, as there was not adequate information concerning the age and length features of $B$. lorteti, the comparisons were made referring to $B$. luteus, which lived in the same river ecosystem and was catched in the same period.

In the B. lorteti population in Asi River, individuals

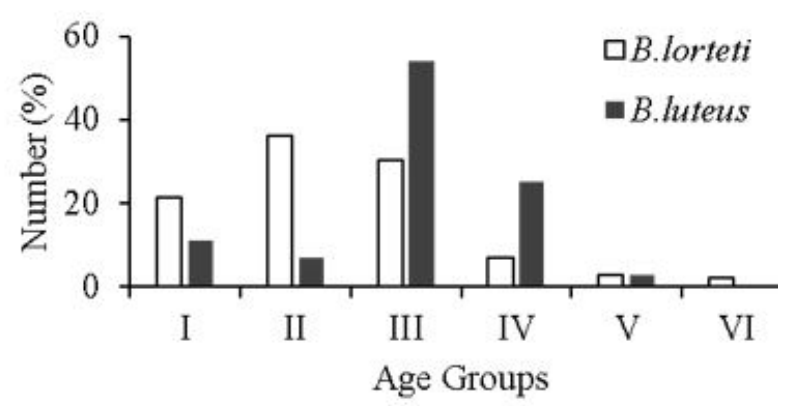

Figure 5. The comparision of condition factor as per the ages of Barbus lorteti and Barbus luteus in the Asi River (Gökçek and Akyurt 2008).

were encounted between the ages of I-VI. In the same period, especially in the research that was made by Yalçın Ozdilek et al. (2004), the age distribution of the $B$. luteus population, changed between the ages of I-V. Gokçek and Akyurt (2008) encountered to $B$. luteus individuals up to the 9 age group. In this case, when the environmental conditions were convenient, they showed a longer length of time compared to $B$. lorteti. As this species involved in the group living long, they continued its population density in our day. As in both of the studies one group of individuals were more dominant which was age 3 for $B$. luteus and age 2 for $B$. lorteti. Mean individual sizes in age groups were higher in length and weight for $B$. lorteti. Especially the individual weights as per the age, was nearly twice as much compared to the $B$. luteus. This comparison was presented in Figure 5 . When the growth features of both species were compared, no significant difference was noticed. However, $\Phi$ prime index of $B$. lorteti (2.56) was found be lower than $B$. luteus (2.65).

In this context, though the age distribution of the $B$. lorteti population was low in the Asi River environment which had negative habitat conditions during the process of time. It was thought that it entered a deterioration process as giving negative reaction due to its relatively high weight. As an example to negative conditions, reduction of the average rainfall in Asi River and the increase of the agricultural irrigation in summer months, could be given. As the reduction in water level made catching in this region easy, it was thought that the population might have limited the age composition (Yalcin, 1997).

In the samples done throughout one year, the individuals in the length group of 7.4 and $31.0 \mathrm{~cm}$, were catched by using the fyke net, electroshocker, trammel net and throw net. Yalcin Ozdilek et al. (2004) obtained the $B$. lorteti in the length group 
of 5.1 and $24.7 \mathrm{~cm}$ in the same region with fyke net, electroshocker and a $17^{*} 17-30^{*} 30 \mathrm{~mm}$ of throw nets. Gokçek and Akyurt (2008) catched the individuals in the length group of 7.5 and $38.4 \mathrm{~cm}$, with $12-34 \mathrm{~mm}$ of gillnet, $12-22 \mathrm{~mm}$ of cast net. In B. lorteti population, no 0 age group individuals were encountered. It was thought that this case was resulted from the catching tool selectivity occurred basing on the mesh openness in the fyke and trammel net. In both of the studies made in the same region in different times, this case was observed in B. luteus population, as well.

In the length-weight relationship which was formed by $B$. lorteti individuals in Asi River, $b$ value was found as 2.97. Yalcin Ozdilek et al. (2004) estimated the $b$ value as 3.08 in the same river system. Gokcek and Akyurt (2008) found $b$ value as 2.97 for female and 3.0 for male indiviauals seperately. It could be said that when the $b$ value was taken into consideration, the $B$. lortet $i$ individuals were achieved isometric growth in Asi River. The sample population obtained from Asi River, was fixed to be ranged between $3.8 \mathrm{~g}$ and $299.0 \mathrm{~g}$.

Yalcin Ozdilek et al. (2004) found that the B. luteus population in this region varied between $2.1 \mathrm{~g}$ and $187 \mathrm{~g}$. In $B$. lorteti population, $\mathrm{L}_{\infty}$ value was found as $28.45 \mathrm{~cm}$. In $B$. luteus population which was catched from the same environment, $L_{\infty}$ value was found as $25.89 \mathrm{~cm}$ by Yalcin Ozdilek et al. (2004), $38.77 \mathrm{~cm}$ for female and $40.32 \mathrm{~cm}$ for male individuals by Gokçek and Akyurt (2008). When the $\mathrm{K}^{-1}$ values were examined in the length growth, it was found as 0.43 in B. lorteti population; while in $B$.luteus population the values of $0.23,0.30$ were found.

$\mathrm{W}_{\infty}$ value in the $B$. lorteti population was determined as $501.04 \mathrm{~g}$. B. luteus individuals revealed the $318.53 \mathrm{~g} \mathrm{~W}_{\infty}$ value (Yalcin Ozdilek et al., 2004). Gokçek and Akyurt (2008) were found $B$. luteus $\mathrm{W}_{\infty}$ value as $750.40 \mathrm{~g}$. When the condition factor was examined as per the ages, it was seen that there was significant difference (Figure 5).

Studying the population dynamic parameters of $B$. lorteti living in Asi River, has provided the exposure of the growth features. Moreover this may contribute to the explanation of the deterioration of this species. Especially, the determination of growth and other biological features of the species living in this type of river systems, could be beneficial for both the sustainability of the natural populations and the fishing management studies. This species might have been subjected to over catching in that period unlike from B. luteus. As it is a hardly encounter species, it is difficult to get information about the minimum legal catching size due to its first reproduction size. Particularly, determining the growth and other biological features of the populations which faced with the danger of extinction, would be beneficial in respect to take the protective measures of the stock.

\section{Conclusion}

As a result, this study is very important as it was the first data giving the growth features of the rarely encountered species while determining the history of the river ecosystem at the same time. In addition, this paper confirms that the population of $B$. lorteti is rarely encountered species in the Asi River and this species might be represented by small isolated populations or really extinct in the river. Asi River have ben exposed to various anthropogenic threats such as pollution, water restrictions, barriers, invasives, overexploitation etc. (Yalçın Özdilek et al., 2004). These adverse conditions might be responsible for decreasing populations not only for B. lorteti, but also for decreasing other endemic/native fish species. We suggest further detailed survey for determining living populations along the river and its tributaries. We also suggest to be arranged an effective management plan for sustainable use of freshwater fish species for river basin.

\section{Acknowledgements}

We would like to thank to Dr. Emre Keskin to verified the species as B. lortetti using DNA test.

\section{COMPLIANCE WITH ETHICAL STANDARDS}

Authors' Contributions

Authors contributed equally to this paper.

Conflict of Interest

The authors declare that there is no conflict of interest.

Ethical Approval

For this type of study, formal consent is not required. 


\section{References}

Beverton, R. J. H. \& Holt, S. J. (1957). On the dynamics of exploited fish populations. Fisheries Investigations Series I/, 19: 1-533.

Crivelli, A. J. (1995). Are fish introductions a threat to endemic freshwater fishes in the northern Mediterranean region?. Biological Conservation, 72(2): 311-319.

Crivelli, A. J. (2018). Luciobarbus Iorteti(amended version of 2006 assessment). The IUCN Red List of Threatened Species 2018: e.T61367A136078059. Retrieved on 01 July 2021 from https://dx.doi.org/10.2305/IUCN.UK.2018-2.RLTS.T61367A136078059.en.

Çiçek, E., Fricke, R., Sungur, S. \& Eagderi, S. (2018). Endemic freshwater fishes of Turkey. FishTaxa, 3(4): 1-39.

Demirci, S. \& Demirci, A. (2009). The fisheries structure of Asi River. Journal of FisheriesSciences.com, 3(2): 163-168. (In Turkish)

Demirci, S., Akar, Ö., Șimșek, E., Demirci, A. \& Yalçın Özdilek, Ș. (2020). Biological parameters and current status of European eel (Anguilla anguilla Linnaeus, 1758) from Asi River, Northeastern Mediterranean region, Turkey. Journal of Applied Ichthyology, 36(6): 918-923.

Demirci, S., Demirci, A. \& Özyllmaz, A. (2018). Biological sustainability in dams: Fish passages, International Erdemli Symposium, Proceedings Book, 890-893.

Demirci, S., Yalçın Özdilek, S. \& Șimșek, E. (2012). A preliminary study on nutrition characteristics of Garra rufa on the river Asi. National Symposium on Fisheries and Aquatic Sciences, Abstract Book, 61. (In Turkish)

Demirci, S., Yalcin Ozdilek, Ș. \& Șimșek, E. (2016). Study on nutrition characteristics of Garra rufa on the river Asi. Fresenius Environmental Bulletin, 25(12a): 5999-6004.

Froese, R. \& Pauly, D. (2010). FishBase. World Wide Web electronic publication. Retrieved on June 21, 2021 from http://www.fishbase.org/Country/ CountryChecklist.php?c_code=792\&vhabitat=fresh\&csub_code=

Gökçek, C. K. \& Akyurt, I. (2008). Age and growth characteristics of himri barbel (Barbus luteus Heckel, 1843) in Orontes River, Turkey. Turkish Journal of Zoology, 32(4): 461-467.

Holden, M. J. \& Raitt, D. F. S. (1974). Manual of fisheries science. Part 2-Methods of resource investigation and their application. Food and Agriculture Organization of the United Nations.

Innal, D. \& Erk'akan, F. (2006). Effects of exotic and translocated fish species in the inland waters of Turkey. Reviews in Fish Biology and Fisheries, 16(1): $39-50$

Karataș, A., Filiz, H., Erciyas-Yavuz, K., Özeren, S. C. \& Tok, C. V. (2021). The vertebrate biodiversity of Turkey. Biodiversity, Conservation and Sustainability in Asia: Volume 1: Prospects and Challenges in West Asia and Caucasus, 175.

Lagler, K. F. (1966). Freshwater Fishery Biology. Dubuque, IA, USA: WMC Brown Company.

Ricker, W. E. (1975). Computation and interpretation of biological statistics of fish populations. Fisheries Research Board of Canada Bulletin, 191.

Sala, O. E., Chapin, F. S., Armesto, J. J., Berlow, E., Bloomfield, J., Dirzo, R., Huber-Sanwald, E., Huenneke, L. F., Jackson, R. B., Kinzig, A., Leemans, R., Lodge, D. M., Mooney, H. A., Oesterheld, M., LeRoyy Poff, N., Sykes, M. T., Walker, B. H., Walker, B. \& Wall, D. H. (2000). Global biodiversity scenarios for the year 2100. Science, 287(5459): 1770-1774.

Spare, P. \& Venema, S. C. (1998). Introduction to tropical fish stock assessment. FAO Fisheries Technical Paper, 306(2): 407.

Yalçın, Ș. (1997). Fishes of Asi River (Orontes). IX. National Water Products Symposium (Symposium Organising Committee, ed.) Isparta: Süleyman Demirel University, Proceedings Book, 73-80. (In Turkish)

Yalçın, Ș. (1999). Some biological characteristics found in Clarias gariepinusthe Orontes River Basin. Gazi University Institute of Science Biology Education Ph.D., 179 p. (In Turkish)

Yalçın-Özdilek, Ș., Gümüș, A. \& Dekker, W. (2006). Growth of European eel in a Turkish river at the south-eastern limit of its distribution. Electronic Journal of Ichthyology, 2: 55-64.

Yalçın-Özdilek, S., Turan, C., Solak, K., \& Akyurt, I. (2004). The growth of Barbus luteus (Heckel, 1843) in the River Asi. Turkish Journal of Aquatic Life, 2(3): 168-174.

Watanabe, K., Sakai, H., Sanada, T. \& Nishida, M. (2018). Comparative phylogeography of diadromous and freshwater daces of the genus Tribolodon (Cyprinidae). Ichthyological Research, 65(3): 383-397. 